\author{
Victoriya Tyshchenko \\ Simon Kuznets Kharkiv National University of Economics \\ 9a Nauky Ave., Kharkiv, Ukraine, vf hneu@ukr.net
}

Julia Kholodna

Simon Kuznets Kharkiv National University of Economics

9a Nauky Ave., Kharkiv, Ukraine, yulia.kholodna@hneu.net

\author{
Alina Krasna \\ Simon Kuznets Kharkiv National University of Economics \\ 9a Nauky Ave., Kharkiv, Ukraine, alina.krasna@hneu.net \\ (D) https://orcid.org/0000-0003-2015-3787
}

\title{
ANALYSIS OF INNOVATIVE ACTIVITIES OF SMALL AND MEDIUM-SIZED ENTERPRISES AS FUNDAMENTALS OF THEIR SUSTAINABLE ECONOMIC DEVELOPMENT
}

\begin{abstract}
This article seeks to address the pressing issue of developing the innovative activity of the domestic economy through the use of the potential of small and medium-sized enterprises, which has to do with the possibility of application of existing experience of the more developed foreign countries in order to achieve economic success. The purpose of this study is to examine the trends in the development of innovative activity of small and medium-sized enterprises in Ukraine, as well as to determine the distribution of the total amount of expenditures by areas of innovation. Analysis of the literature on this issue has shown that the economic development of a country depends on many factors, and the use of intellectual potential is quite a significant factor in modern society. The relevance of this issue is supported by the fact that the majority of developed countries that have high levels of national income and are distinguished by the quality of life of the population are introducing the latest innovative inventions and using them appropriately in: production, agriculture, trade and other fields of activity. The research of the development of innovation activity of small and medium-sized enterprises in the article is carried out in the following logical sequence: analysis of small and medium-sized enterprises in Ukraine, analysis of small and medium-sized enterprises of EU countries, evaluation and comparison of innovation activity of Ukraine and EU countries. The methodical tools of the study included methods of statistical analysis. The study period was 2010-2018. The object of analysis is the process of development of innovation activity of small and medium-sized enterprises, as they are the majority of enterprises in Ukraine. The article presents the results of the analysis of the state of innovation the activity of small and medium-sized enterprises, which showed that our country needs significant transformation in this direction. Studies show that increasing the turnover and the production of small and medium-sized enterprises depends on the level of innovative development. The results of the study may be useful for small and medium-sized enterprises.
\end{abstract}

\section{Keywords}

innovation, scientific and technical activity, technological readiness, innovation development, innovation activity, small and medium-sized enterprises.

\section{Introduction}

The development of innovation activity of the domestic economy through the use of the potential of small and medium-sized enterprises is a pressing issue, which has to do with the possibility of application of the existing experience of the more developed foreign countries in order to achieve economic success. The term and concept of "innovation" as a new economic category was introduced into scientific circulation by the Austrian (later American) scientist J. Schumpeter [0]. The economic development of a country depends on many factors, and the use of intellectual potential is quite a significant factor in modern society. The majority of developed countries, which have high levels of national income and are distinguished by the quality of life of the population, are introducing the latest innovative inventions and using them appropriately in production, agriculture, trade and other fields of activity. The increase in the turnover and the production of small and medium-sized enterprises directly depends on the level of innovative development. New and demanded goods and services are the main factor of the existence and competitiveness of these enterprises. The rapid changes in consumer needs, the updates of quality requirements, the small life cycles of goods or services and the increase in their diversity 
are all due to the fact that the production of small and medium-sized enterprises has to be modernized in the shortest possible time. Innovation is a key condition for the development of any enterprise and the economy of the country.

\section{Method of research}

The author proposes to review the general condition of small and medium-sized enterprises in Ukraine - to evaluate the component of small and medium-sized enterprises in the economy of the country, to determine the volume of sales of small and medium-sized enterprises and to identify the main types of economic activity of small and medium-sized enterprises.

The next step in analyzing the statistical information on the innovative activity of small and medium-sized enterprises (SMEs) will be to analyze SMEs in the EU. First, the EU's SMEs are evaluated, and then the innovation performance of EU countries is evaluated - the proportion of EU enterprises that have had innovative products, the innovative SMEs of the EU, the distribution of innovative SMEs by major types of innovation, the Summary Innovation Index (SII) of EU countries, SMEs with innovative products or processes, marketing or organizational innovations and SMEs' innovations in their own businesses.

The last step is to conduct an assessment of Ukraine's innovative activity - the main indicators of Ukraine's innovation activity, the "Innovation" and "Technological Readiness" sub-indices of the GCl rating. After assessing the state of innovation, a consideration of the intensity of innovation spending of Ukraine with other countries and an analysis of the distribution of sources of financing the innovation activity of industrial enterprises are proposed.

\section{Results}

In 2017, the number of large enterprises in Ukraine amounted to 399 (0.02\% of the total number of economic entities), the remaining $99.98 \%$, including 15,524 medium-sized enterprises and business entities, 322,920 small enterprises (incl. micro-enterprises) and 1.4 million small and micro-sized business entities (0).

Consider the dynamics of changes in economic entities for 2010-2017. (Table 1). We see a downward trend in the number of working enterprises, so compared to 2010 , the number of large enterprises decreased by $32 \%$ and in 2017 amounted to 399. The number of medium-sized business entities also decreased by $28 \%$ in 2017 compared to 2010 . The number of small business entities decreased by $23 \%$, micro entities by $17 \%$.

Analyzing the volume of sold products (goods, services) we can say that the ratio for 2010-2017 remains almost unchanged (Fig. 1). In 2017, the share of large entities accounted for $35.2 \%$ of the total sales, the medium entities $39.9 \%$, small and micro entities $12.2 \%$ and $12.7 \%$ respectively.

Table 1. Indicators of Structural Statistics by Economic Entities with Size Distribution

\begin{tabular}{|c|c|c|c|c|c|c|c|c|c|}
\hline & $\begin{array}{l}\bar{\pi} \\
\text { 。 }\end{array}$ & 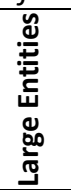 & 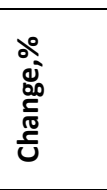 & 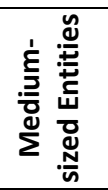 & 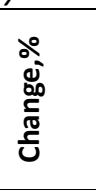 & 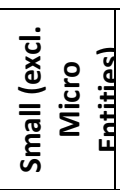 & 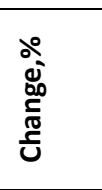 & 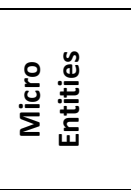 & 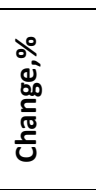 \\
\hline \multicolumn{10}{|c|}{ Number of Economic Entities } \\
\hline 2010 & 2183928 & 586 & N/A & 21338 & N/A & 68316 & $\mathrm{~N} / \mathrm{A}$ & 2093688 & N/A \\
\hline 2011 & 1701620 & 659 & +12.46 & 21059 & -1.31 & 71083 & 4.05 & 1608819 & -23.16 \\
\hline 2012 & 1600127 & 698 & +5.92 & 20550 & -2.42 & 68103 & -4.19 & 1510776 & -6.09 \\
\hline 2013 & 1722070 & 659 & -5.59 & 19210 & -6.52 & 65021 & -4.53 & 1637180 & +8.37 \\
\hline 2014 & 1932161 & 497 & -24.58 & 16618 & -13.49 & 55159 & -15.17 & 1859887 & +13.60 \\
\hline 2015 & 1974318 & 423 & -14.89 & 15510 & -6.67 & 47555 & -13.79 & 1910830 & +2.74 \\
\hline 2016 & 1865530 & 383 & -9.46 & 15113 & -2.56 & 49298 & +3.67 & 1800736 & -5.76 \\
\hline 2017 & 1805059 & 399 & +4.18 & 15254 & +0.93 & 52324 & +6.14 & 1737082 & -3.53 \\
\hline
\end{tabular}




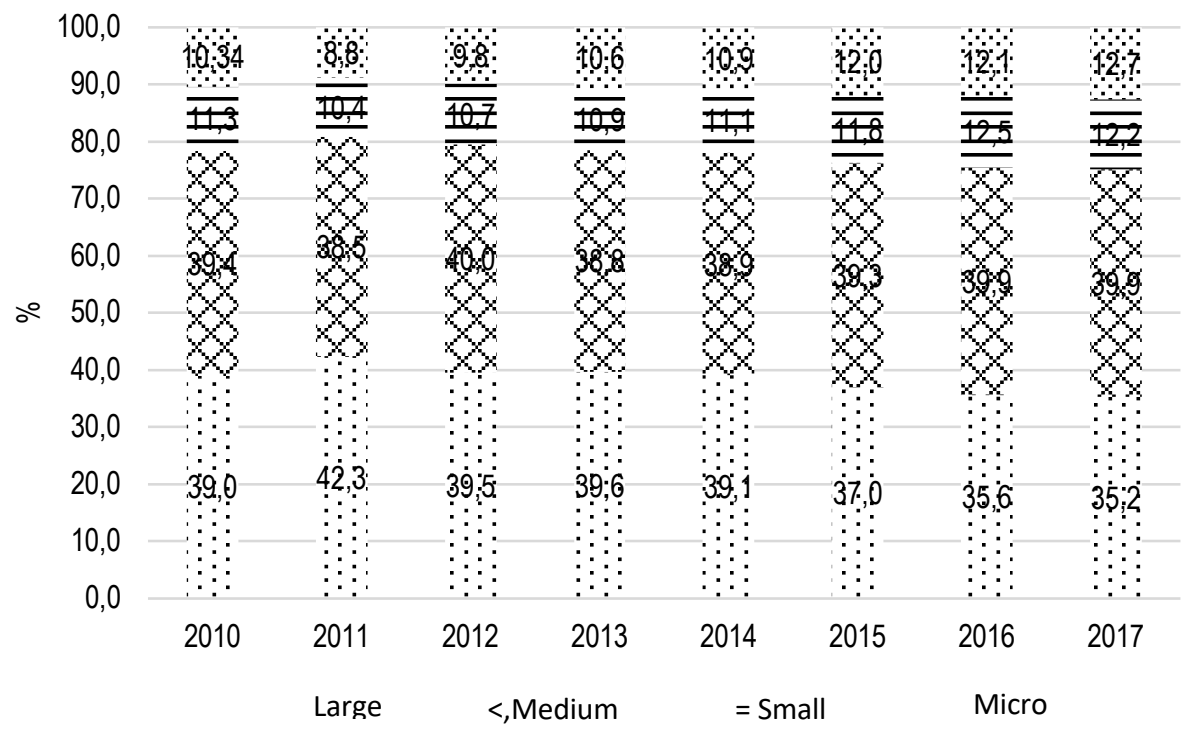

Figure 1. Distribution of Sales of Enterprises by Size in 2010-2017\% of Total Sales (Compiled by the Author) [2]

Thus the volume of sales of enterprises in modern conditions is the most important performance indicator of economic activity. The volume of sales of SMEs is $64 \%$ which is the majority. The value of this indicator is affected by fluctuations in structure and physical sales volume and changes in product prices. To increase sales volumes is the following are recommended for businesses:

- $\quad$ Produce competitive and quality products (services)

- Expand the range of goods or services

- Effectively use labor resources

- Carry out innovative activity.

Analyzing the 2018 Summary Innovation Index (SII) for each EU country, the highest rates are in: Sweden (0.71) Finland (0.70) and Denmark (0.68) against 2010 Sweden (0.68) Denmark (0.66) Finland (0.63). The lowest rates are in: Romania (0.16) Bulgaria (0.23) Poland (0.29) against Romania (0.22) Latvia (0.23) Bulgaria (0.24). According to this index, the leading countries have changed in 2018. Finland was in second place compared to third in 2010. Denmark is in 3rd place (against 2 nd in 2010) and the Netherlands are in 4th place (+2 positions) [3] (Fig. 2). 


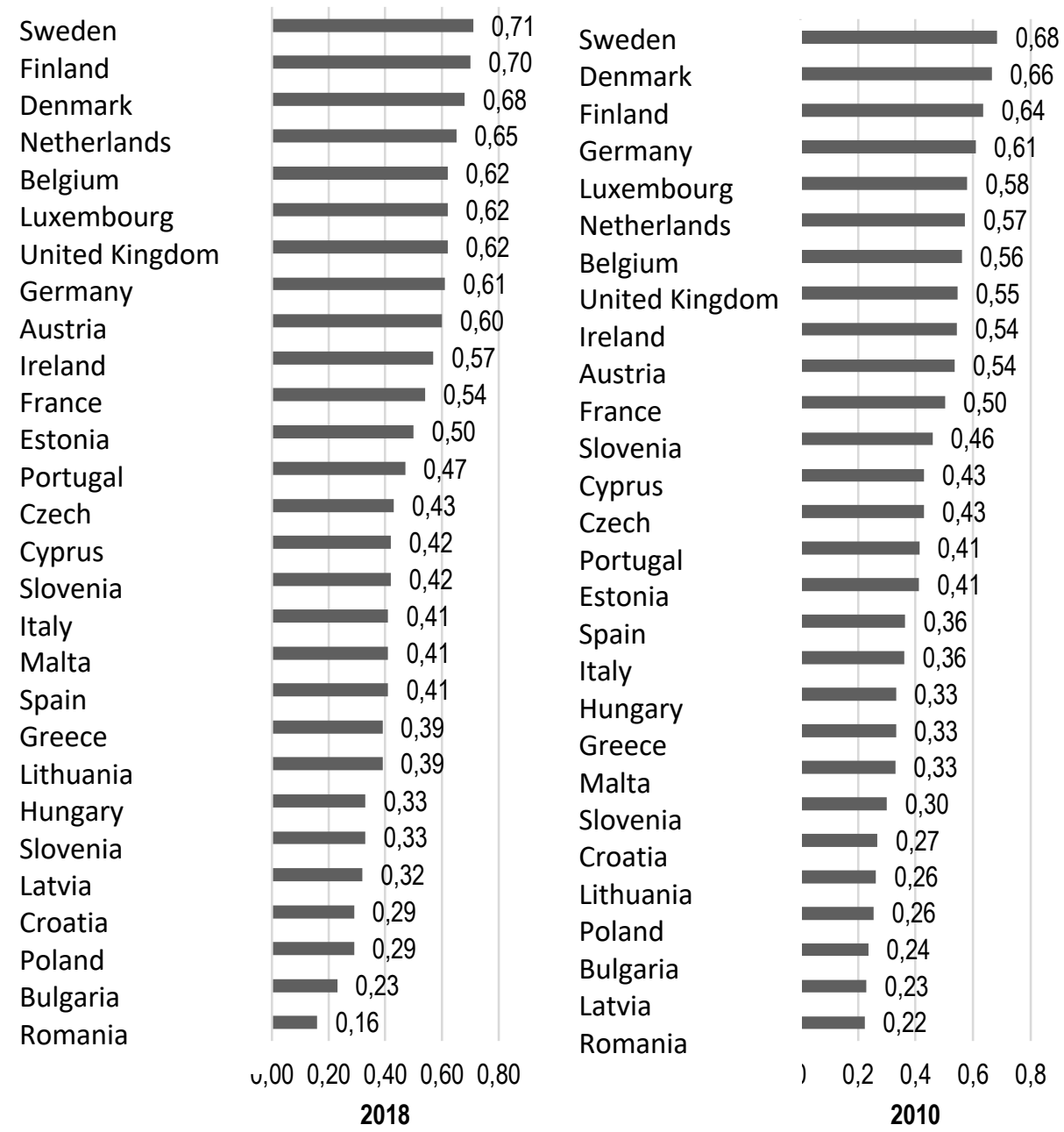

Figure 2. Summary Innovation Index (SII) of EU Countries in 2018 Compared to 2010 [3]

Comparing EU innovation performance in 2010 we can say that in 2018 they increased by an average of $5.8 \%$. In the last 8 years, innovative activity has grown in $18 \mathrm{EU}$ countries and decreased in ten.

The following are: Denmark - environment for human resources and innovation; Luxembourg - attractive research systems; France - finance and support; Ireland - innovation in SMEs and employment and sales impact; Belgium - innovative relations and cooperation [3].

Given the global trends of globalization, an international comparative analysis of innovative trends is of particular importance in order to answer the question of Ukraine's place in the global innovation process. Innovative capacity and technological readiness are integral components of the competitiveness of the national economy. According to the report of the World Economic Forum on Global Competitiveness, Ukraine's rating under the "Innovation" sub-index increased to 61st place in 2016-2018 compared to 93rd in 2013-2014 climbing 32 positions in the rating (Table 2). The growth in this rating (compared to 2013) was influenced by the improvement in almost all its components in particular: innovative capacity (+49 positions) quality of research institutes ( +9 positions) companies' expenditures on research and development (+36 positions) university relations with industry (+4 positions) government procurement of the latest technology and products (+22 positions). The quality of these components depends first and foremost on the efforts of the state to finance the costs of research and development, the acquisition of external knowledge, as well as machinery equipment and software. 
Table 2. Innovation and Technology Readiness Sub-indices of GCl Rating for Ukraine

\begin{tabular}{|c|c|c|c|c|c|c|c|c|c|c|c|}
\hline \multirow[b]{2}{*}{ Components of the Global Competitiveness Index } & \multicolumn{2}{|c|}{$2013-2014$} & \multicolumn{2}{|c|}{ 2014-2015 } & \multicolumn{2}{|c|}{ 2015-2016 } & \multicolumn{2}{|c|}{ 2016-2017 } & \multicolumn{2}{|c|}{$2017-2018$} & \multirow{2}{*}{$\begin{array}{c}2013-2018 \\
\text { Rating } \\
\text { Deviation }\end{array}$} \\
\hline & 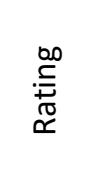 & 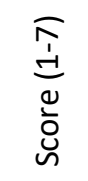 & 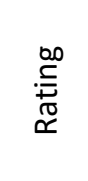 & 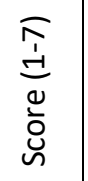 & 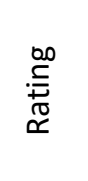 & $\begin{array}{l}\underset{1}{ \pm} \\
\stackrel{ \pm}{\nu} \\
\stackrel{0}{0} \\
\sim\end{array}$ & 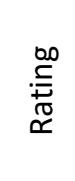 & 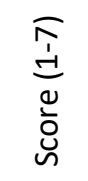 & 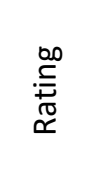 & 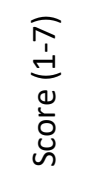 & \\
\hline \multicolumn{12}{|c|}{ Innovation sub-index and its components } \\
\hline Innovation & 93 & 3.0 & 81 & 3.2 & 54 & 3.4 & 52 & 3.4 & 61 & 3.4 & +32 \\
\hline Innovative capacity & 100 & 3.2 & 82 & 3.6 & 52 & 4.2 & 49 & 4.4 & 51 & 4.3 & +49 \\
\hline Quality of research institutes & 69 & 3.6 & 67 & 3.8 & 43 & 4.2 & 50 & 4.2 & 60 & 3.9 & +9 \\
\hline Research and development (R\&D) spending of companies & 112 & 2.7 & 66 & 3.1 & 54 & 3.4 & 68 & 3.3 & 76 & 3.2 & +36 \\
\hline Relationships between universities and industry in R\&D & 77 & 3.4 & 74 & 3.5 & 74 & 3.5 & 57 & 3.5 & 73 & 3.4 & +4 \\
\hline Public procurement of the latest technologies and products & 118 & 3.0 & 123 & 2.9 & 98 & 3.0 & 82 & 3.1 & 96 & 3.0 & +22 \\
\hline Presence of scientists and engineers & 46 & 4.5 & 48 & 4.3 & 29 & 4.7 & 29 & 4.7 & 25 & 4.7 & +21 \\
\hline Number of patents received in the US (per million people) & 52 & 2.9 & 52 & 3.2 & 50 & 3.6 & 49 & 3.9 & 52 & 3.6 & 0 \\
\hline \multicolumn{12}{|c|}{ Technological readiness sub-index and its components } \\
\hline Availability of the latest technologies & 106 & 4.3 & 113 & 4.1 & 96 & 4.3 & 93 & 4.3 & 107 & 4.1 & -1 \\
\hline The level of technology development & 100 & 4.3 & 100 & 4.2 & 100 & 4.2 & 74 & 4.4 & 84 & 4.3 & +16 \\
\hline Foreign direct investment and technology transfer & 131 & 3.6 & 127 & 3.7 & 117 & 3.8 & 115 & 3.7 & 118 & 3.5 & +13 \\
\hline Internet users & 93 & 33.7 & 82 & 41.8 & 80 & 43.4 & 80 & 49.3 & 81 & 52.5 & +12 \\
\hline Broadband Internet access & 71 & 8.1 & 68 & 8.8 & 72 & 8.4 & 64 & 11.8 & 63 & 12 & +8 \\
\hline High-frequency Internet & 84 & 14.3 & 50 & 52.9 & 64 & 40.7 & 68 & 45.7 & 54 & 79.9 & +30 \\
\hline Broadband mobile coverage & 94 & 5.5 & 107 & 5.4 & 121 & 7.5 & 130 & 8.1 & 115 & 22.6 & -21 \\
\hline
\end{tabular}

Source: Author's based on [4] 
Activities of the enterprises themselves also directly influences these components since the they prefer using foreign technology to a greater extent through licensing over their own development and research. The rating of the "number of patents received in the United States" remained unchanged. Particular attention should be paid to the technological readiness sub-index, the rating for which is constantly increasing and which is associated with the rise in place all its components (see Table 2) except for the position of the "Broadband Mobile Coverage" index (-21 positions compared to 2013-2018) and the "availability of the latest technologies" index (-position).

The main reasons for the increase in technological readiness in Ukraine can be attributed to the following: the Ukrainian economy mainly started utilizing new technological advances; innovative activity of enterprises (compared to EU countries) started to increase; improvement of legal instruments for the protection of property rights.

In terms of "Technological Readiness" (Fig. 3) in 2017-2018 Luxembourg, Switzerland, the Netherlands and the United Kingdom took the leading positions confirming the correlation between the level of innovation and the overall development of the country. These countries have not only maintained their position but also improved their results.

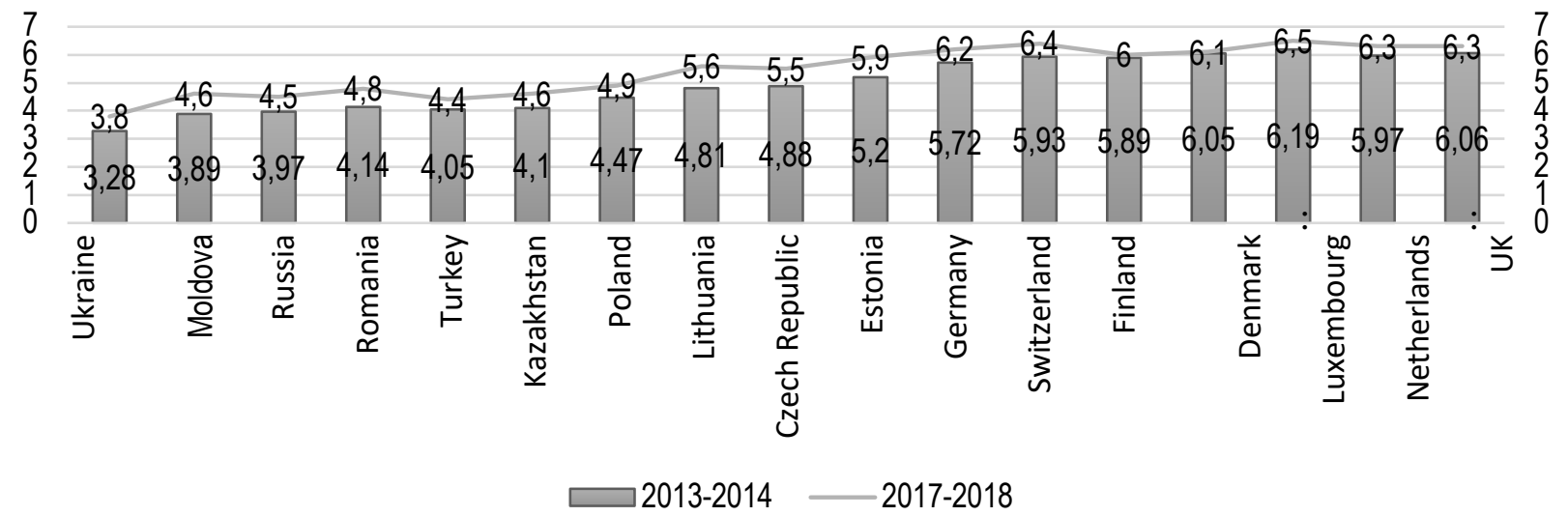

Figure 3. Ratings of Ukraine and Other Countries under the "Technological Readiness" Index Compiled from [4]

Ukraine had a positive trend and climbed 13 places in the ranking (94th place in 2013 81st place in 2018). This is due to the fact that the pace of technological growth in Ukraine is rising significantly. Countries of the former Soviet Union have also increased the value of their indices which indicates a certain development in the fields of information mobilization, Internet distribution and more. The development of innovation activity in the regions of Ukraine is extremely uneven which is largely related to the level of development of the innovation infrastructure. The analysis of the existing infrastructure of innovative activity in Ukraine firstly testifies to its underdevelopment, functional incompleteness and inability to reach all links of the innovation process. Switzerland, the United States, Israel and Finland which in the period from 2013 to 2018 have improved their positions (Fig. 4) also take the top places in the rating of innovation countries (sub-index "Innovation"). 


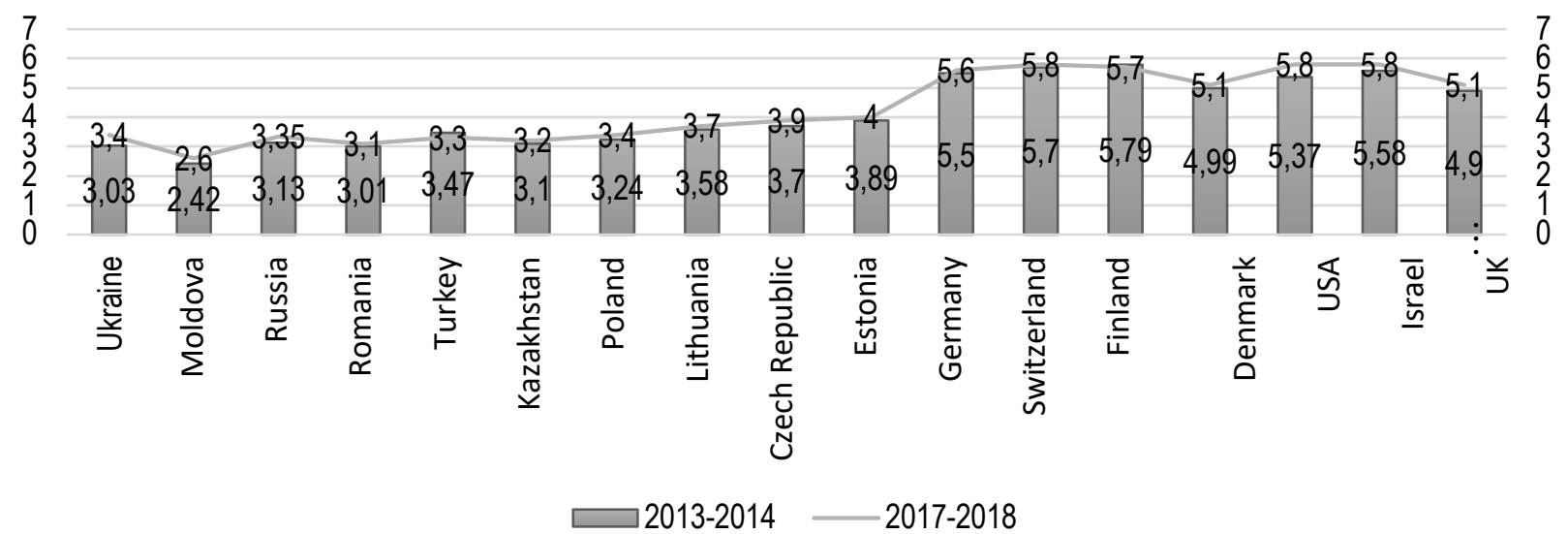

Figure 4. Ratings of Ukraine and Other Countries under the "Innovation" Index Compiled from [4]

The general trends of global development together with a real assessment of the level of scientific technical and innovative activity in our country testify to the threat of danger of being left out of the global processes of formation of a powerful innovation system. The lack of a comprehensive system for managing innovation processes in the country and the state-imposed repression of innovators initiated in 2005 have led to the following negative consequences:

1. The share of innovative products sold in total industrial production declined to $0.8 \%$ in 2018 (one of the lowest values in the last ten years) (Fig. 5) which is due to a decrease in consumer demand and the demand for industrial products caused by the financial and economic crisis.

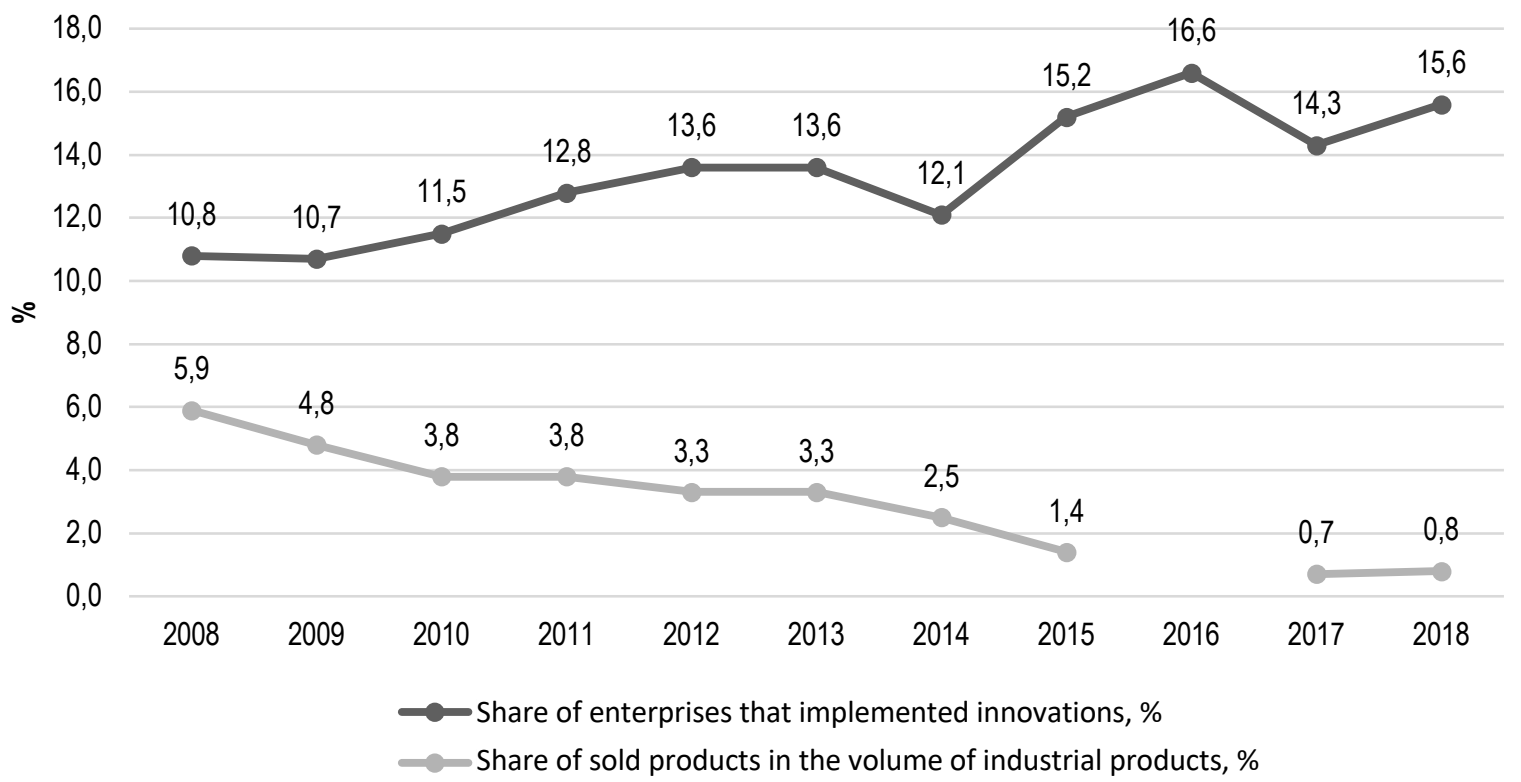

Figure 5. Main Indicators of Innovation Activity of Ukraine Compiled from [2]

Despite the growth of the share of innovative enterprises (by $4.8 \%$ in 2018 compared to 2008) in this indicator, our country is significantly behind the European countries where the share of innovators is from $30 \%$ (Croatia, Czech Republic) to 65\% (US, Germany, Japan). In Ukraine the innovative activity of industrial enterprises is at a level that does not reach even the minimum value among European countries, and if compared to the leading countries in terms of innovative development, the gap is about 5 times. The consequence of the formation and consolidation of a model of economy in Ukraine built mainly on low-tech industries and paradigms was the deepening in the industrial complex of the tendency of dominance of industries with low scientific intensity. Of the total number of innovatively active enterprises almost $95 \%$ were in the processing industry, which corresponds to the global trends in the development of processing enterprises due to the need to maintain the competitiveness of their products compared to foreign counterparts by actively participating in the implementation of innovative developments. 
The effectiveness of the innovation spending structure is the topical issue. In 2010-2018 innovative enterprises spent a significant portion of their costs on the purchase of machinery equipment and software (Fig. 6) which is the highest indicator among other types of costs (62.79\% in 2010 versus $68.07 \%$ in 2018 year). Much less funds were used to fulfill external $R \& D$ and acquire external $R \& D$ and other external knowledge. These figures range from $1.7 \%$ to $6.93 \%$. The level of costs for the acquisition of new technologies - the lowest of the directions of expenses - shows that the domestic business does not accept the latest achievements of science and technology. Sweden's R\&D expenditure accounts for $63.2 \%$, the Netherlands $-62.5 \%$, Luxembourg - 53.8\%, Belgium - 42\%, Turkey - 28.9\%, Poland - 8.3\%, Romania - $13.4 \%$, the Czech Republic - $23.2 \%$ Russia - $15 \%$ of the total costs of innovation. Research and development costs exceed investment in equipment in Belgium, Iceland and Luxembourg by 1.5-2 times. In Eastern Europe investment is more focused on upgrading fixed assets. Cost relations for research and equipment purchase are: in Bulgaria 1:19, Estonia 1:8, Poland and Slovakia 1:7, Russia $1: 6$.

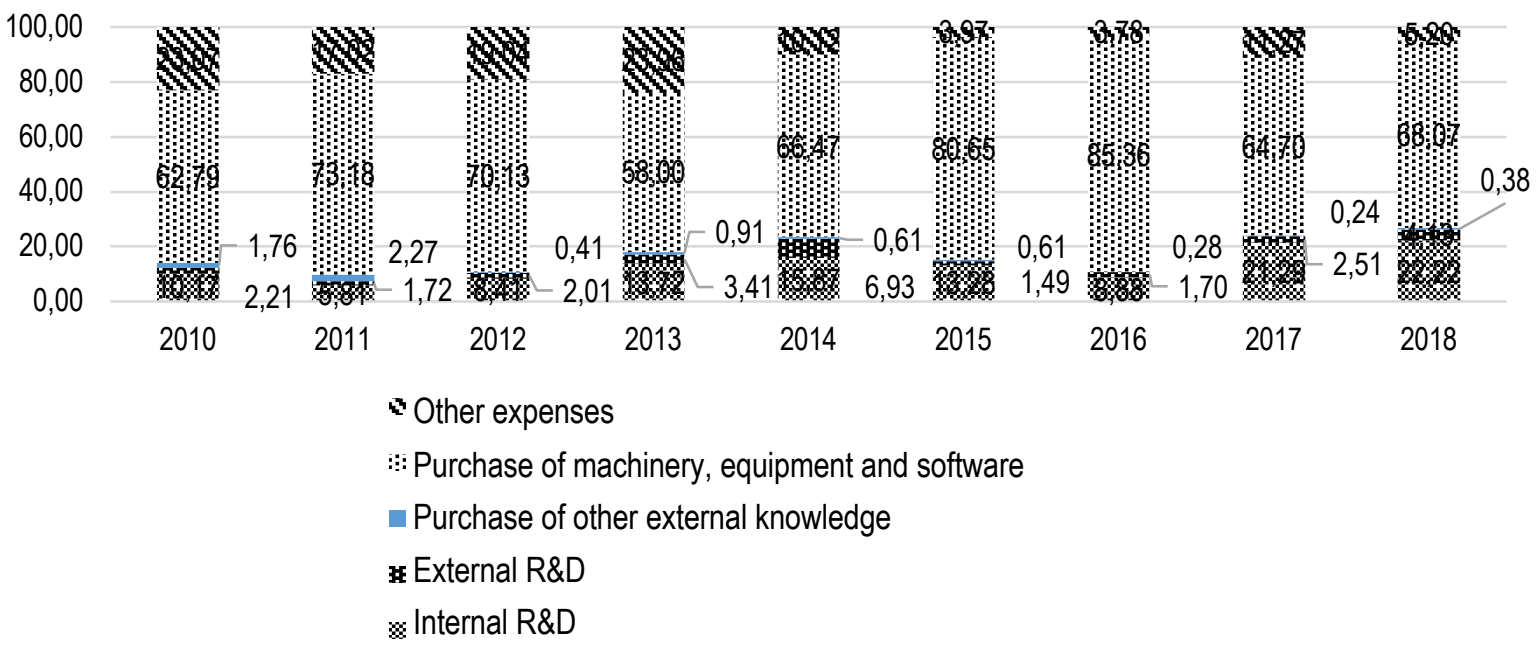

Figure 6. Allocation of Total Expenditures by Areas of Innovation in 2010-2018\% of Total Expenditures (Compiled from [2])

Considering the distribution of sources of financing of innovative activity for 2010-2018 (Fig. 7) it may be noted that the own funds are spent the most. In 2010-2014 there was a significant proportion of foreign investors (in the range of $1.8-29.97 \%$ ) but since 2015 , this financing has stopped which is explained by the instability in the economic situation of the country. 


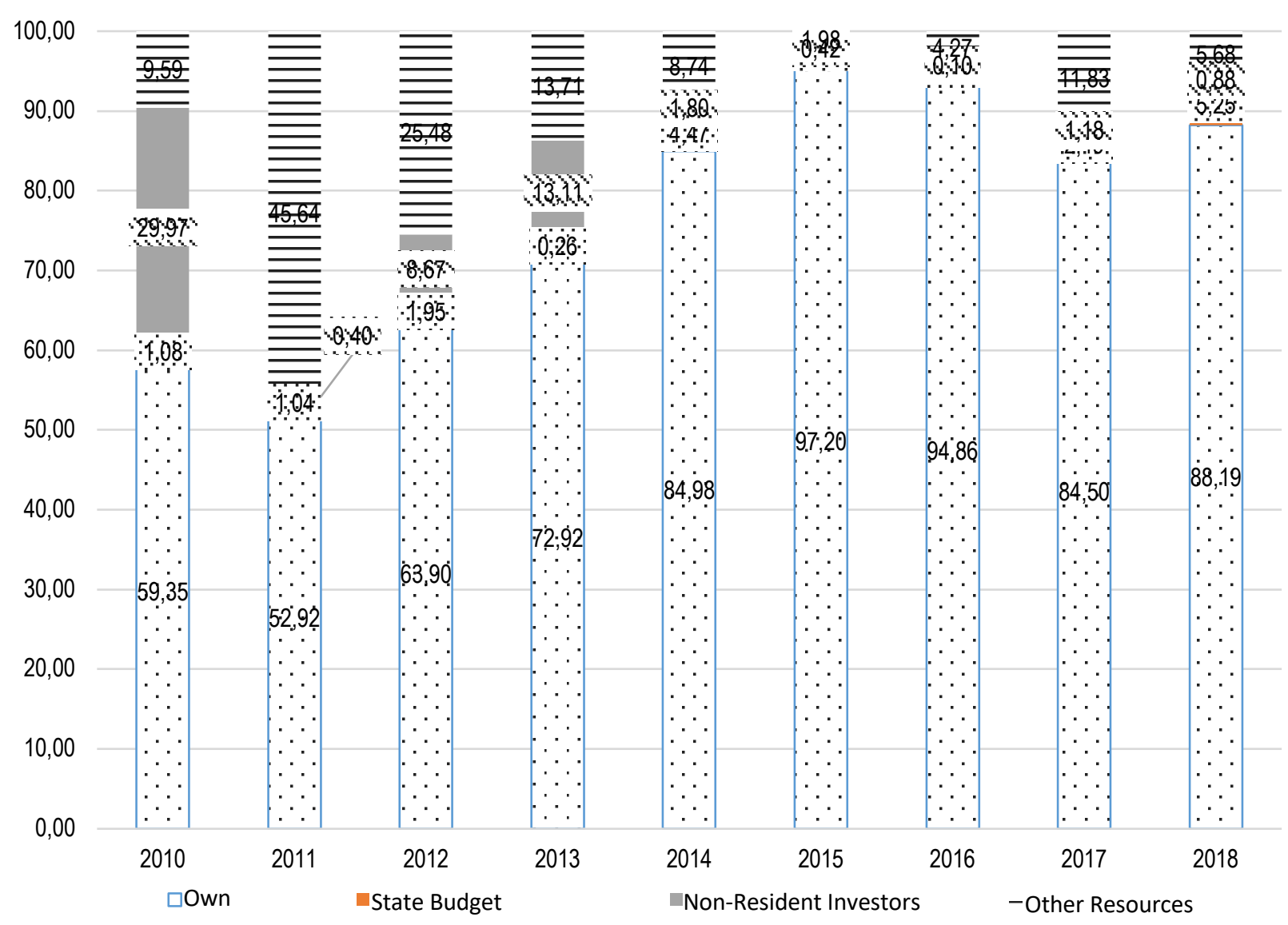

Figure 7. Distribution of Sources of Financing of Innovative Activity of Industrial Enterprises in 2010-2018 $\%$ of Total Financing [2]

\section{Discussion the other scientists and papers}

The economic content features problems of innovative development are actively discussed in the writings of economists. Studies of innovative development of the national economy have been reflected in the works of foreign and domestic scientists. While examining models of economic growth, the Nobel Prize winner in Economics D. Hicks [5] came to the conclusion that it is innovation that creates the stability of a market economy. Also the study of the role of innovative processes in the economy was discussed in their works by such prominent foreign scientists as M. Kondratyev [6] M. Porter [7] Yu. lakovets [0] et al. Considering the works of domestic authors, we should highlight the works of $\mathrm{V}$. Heits [0] et al. The state and development of the financial and economic component of the innovative infrastructure of the region are discussed in the works of $P$. Bubenko [0] O. Amoshi [0] et al.

\section{Uncertainty and impact of research results on science, economy, the environment and society according}

Analyzing the state of development of innovation activity of SMEs we can say that Ukraine is significantly inferior to the world countries in terms of innovative development. Creating preconditions for stimulating innovative growth requires a comprehensive approach from the state and enterprises (Fig. 8). It is the creation of interaction between the state and the SME sector that will promote the existence of healthy competition and stimulate SMEs to innovate. With the introduction of the innovative activity, businesses will be able to increase their profitability and not lose their competitive advantage in the market. The state should also be guided by a longterm strategy for innovative development. 


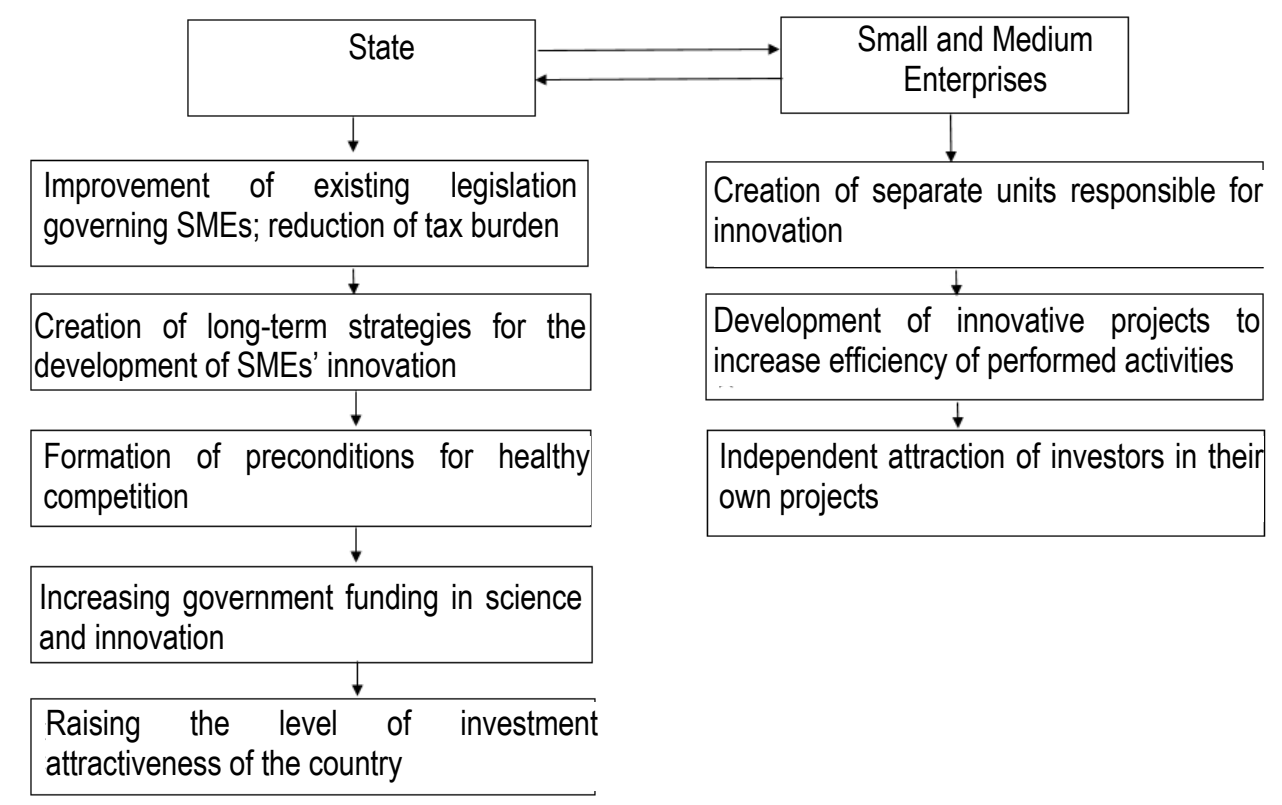

Figure 8. Set of Measures for Improving the State of Innovation of SMEs (Compiled by the Author)

The results of the study show that there is a significant lag behind the more developed countries of the world in Ukraine. An important factor in the growth of economic well-being at the moment is the introduction of innovative activity in enterprises. The SME sector, which is the largest layer among all enterprises, is flexible enough to adapt to new conditions. It is SMEs that can be a catalyst for a country's development.

The results of the study can be used by future researchers to study the role of innovation in small and mediumsized enterprises in the development of the economy.

\section{Summary and conclusions}

To summarize, the conducted analysis shows that the state of innovative activity in Ukraine requires significant changes. A comparison of innovative indicators allowed for an estimation of the level of innovative activity and placed it at the critical level. This is due to the lack of comprehensive support from the state. Particular attention in the development of innovative activity is paid to the SME sector which constitutes the majority (99.98\%). This is because SMEs are focused on innovation while large companies are engaged in the introduction of production and the promotion of goods.

SMEs are the most important actors of innovation because they are the basic condition for the functioning of the innovation economy as well as the main source of innovation and the generator of new ideas. There are a number of constraints on the development of SMEs in Ukraine including the lack of funding sources. In the current conditions, the provision of financial support from the state is insufficient therefore attracting funds from foreign investors is recommended The state needs to create a favorable investment climate for this purpose. The main indicators of the investment climate are the level of inflation, unemployment, lending, tax burden, stability of the national currency, the level of competition etc.

A set of measures is proposed to improve the state of innovation of SMEs which involves the interaction of the state with the latter.

Enterprises should set up separate units for innovative activities which will be responsible for developing innovative projects to increase the efficiency of their performed activities. Funding is an integral component. Therefore, the independent attraction of investment funds into their business will contribute to the growth of innovative activity.

In conclusion it can be noted that improving the innovation activity of SMEs is a necessary direction for the effective development of the domestic economy.

\section{Acknowledgment}

All studies were conducted by the authors themselves (without joining any scientific topic). 


\section{References}

[1] I. A. Shumpeter,Teoriya ekonomicheskogo razvitiya: Issledovanie predprinimatel'skoi pribyli kapitala kredita protsenta i tsikla kon'yuktury / Theory of economic development: a study of entrepreneurial profit capital credit interest and the business cycle, Progress, Moscow,1982.

[2] Official site of the State Statistics Service of Ukraine.(2019). URL: http://www.ukrstat.gov.ua.

[3] Innovation Scoreboard,
https://interactivetool.eu/f/extensions/DGGROW4/EIS 2.html\#a

[4] Global Competitiveness Index, 2017-2018. URL: http://reports.weforum.org/global-competitivenessindex-2017-2018/

[5] D.R. Khiks, Stoimost' i kapital / Cost and Capital, Progress, Moscow, 1993.

[6] N.D. Kondrat'ev,Problemy ekonomicheskoi dinamiki / Problems of economic dynamics, Economics, Moscow, 2002

[7] M.E. Porter, Konkurentsiya / Competition, Vil'yams, Moscow, 2002

[8] Yu. V. Yakovets, Globalizatsiya vzaimodeistviya tsivilizatsii / Globalization of the interaction of civilizations, ZAO "Ekonomika", Moscow, 2003.

[9] V.M. Geets', Innovative prospects of Ukraine / Innovative prospects of Ukraine, Konstanta, Kharkiv, 2006.

[10] P.Bubenko,Klyuchovi momenti formuvannya regional'nikh innovatsiinikh sistem v Ukraïni / Key moments of formation of regional innovation systems in Ukraine, Ekonomika Ukraïni - Ukraine economy 8 33-39, 2007.

[11] O.I. Amosha, V.P. Vishnevs'kii, L.O. Zbarazs'ka, Kontseptual'ni orientiri promislovoï politiki Ukraïni (na seredn'ostrokovu perspektivu) / Conceptual landmarks of industrial policy of Ukraine (in the medium term), Ekonomika Ukraini - Ukraine economy 4-13, 2009. 